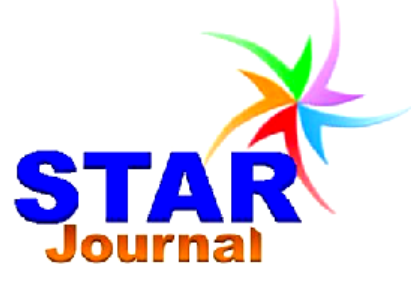

ISSN: 2226-7522(Print) and 2305-3327 (Online) Science, Technology and Arts Research Journal

April-June 2013, 2(2): 30-37

www.starjournal.org

Copyright@2013 STAR Journal. All Rights Reserved

Original Research

\title{
Feed Intake, Digestibility and Growth Performance of Horro Lambs Fed Natural Pasture Hay Supplemented Graded Level of Vernonia amygdalina Leaves and Sorghum Grain Mixture
}

\author{
Firisa Woyessa $^{1^{*}}$, Adugna Tolera $^{2}$ and Diriba Diba ${ }^{1}$ \\ ${ }^{1}$ Departement of Animal Science, College of Agriculture and Natural Resources, Wollega University, \\ Post Box: 395, Nekemte, Ethiopia \\ ${ }^{2}$ Schoool of Animal and Range Sciences, College of Agriculture, Hawassa University, Post Box: 05 \\ Hawassa, Ethiopia
}

\begin{tabular}{|c|c|}
\hline \multirow[b]{2}{*}{$\begin{array}{l}\text { Abstract } \\
\text { This study was undertaken with the objectives of evaluating the effect of dried and ground } \\
\text { Vernonia }(V . \text { amygdalina) leaves and ground sorghum ( } S \text {. bicolor) grain mixture } \\
\text { supplementation on feed intake, digestibility, body weight change, feed conversion } \\
\text { efficiency of Horro lambs fed a basal diet of natural pasture hay. The feeding and } \\
\text { digestibility trials were conducted using twenty male lambs of similar yearling age and } \\
\text { average body weight of } 15.4 \pm 0.58 \mathrm{~kg} \text {. The lambs were blocked into five blocks of four } \\
\text { animals each based on their initial body weight and randomly allocated to four dietary } \\
\text { treatments from each block giving five animals per treatment. Treatment } 1 \text { was fed on } \\
\text { grass hay alone, while treatments } 2,3 \text {, and } 4 \text { received graded levels }(150,300 \text { and } 450 \mathrm{~g} \text {, } \\
\text { respectively) of a mixture of dried and ground Vernonia leaves and ground sorghum grain } \\
\text { mixture as supplements to the grass hay basal diet. Supplementation with dried Vernonia } \\
\text { leaves and sorghum grain mixture improved feed intake, nutrient digestibility and body } \\
\text { weight gain of the lambs as compared to the unsupplemented animals. The body weight } \\
\text { gain of the lambs was lowest in T1 (7.6g/day), intermediate in T2 ( } 40 \text { g/day) and highest in } \\
\text { T3 }(81.3 \text { g/day) and T4 ( } 93.8 \mathrm{~g} / \mathrm{day})(P<0.01) \text {. It was concluded that supplementation of } \\
\text { vernonia leaves and sorghum grain mixture improved feed intake and digestibility of the } \\
\text { diet and body weight gain of the lambs. In general increased performance was observed } \\
\text { with increasing level of supplementation. However, cost-benefit analysis is required to } \\
\text { determine the optimum level of supplementation, particularly as the level of } \\
\text { supplementation exceeds } 300 \mathrm{~g} \text {. }\end{array}$} & \\
\hline & $\begin{array}{l}\text { Article History: } \\
\text { Received }: 29-03-2013 \\
\text { Revised } \quad: 25-06-2013 \\
\text { Accepted }: 27-06-2013\end{array}$ \\
\hline
\end{tabular}

\section{INTRODUCTION}

Ethiopia is known with a large diversity of farm animal species and genetic resources adapted to different agro-ecologies and production systems (MoA, 1999). Sheep is the second most populous and important livestock species in Ethiopia estimated to be 26 million (CSA, 2008). Sheep serve as a source of cash income and source of quality protein, predominantly slaughtered during festive and religious occasions (Berhanu and Aynalem, 2009). Since sheep rearing in most production system takes short time to produce meat, farmers always aim to have sheep that can give the maximum possible lean meat in the shortest possible time. In this regard, Horro lambs have good merits for increased body weight gain post weaning (Kassahun, 2000). However, the existing natural pasture couldn't support these sheep to manifest their genetic potential to the optimum.

Tree and shrub legumes are important in producing large quantities of forage because of their deep-root systems and with correct management can produce green feed for much of the dry season. So indigenous multipurpose trees and legume forages such as Vernonia amygdalina can be used as an alternative protein supplement because of their green leaves and sustainability, but their potential as forage has been subject of little research (Aynalem and Taye, 2008). Foliage from 
Firisa Woyessa et al.,

this plant is commonly available from nurseries, gardens or backyard and farmlands.

Most conventional energy supplements are expensive and not readily available for livestock feeding as they are primarily used as human food. Sorghum grain is one of the energy source concentrates that can be used as human and animal feed. Feeding sorghum grain to lambs and kids improves growth performance of the animals and allows the producer to more easily monitor the health and condition of animals. In general, grainfed livestock grow faster, become fleshier and tolerate the effects of internal parasites better (NRC, 1996).

The research hypothesis is that indigenous multipurpose browse species such as $V$. amygdalina can serve as an alternative protein supplement because of their green fodder production capability, sustainability, low cost and accessibility. Therefore, this Thesis research was conducted with the objective of studying the effect of supplementation with dried and ground Vernonia (V. amygdalina) leaves and ground sorghum (Sorghum bicolor) mixture on feed intake, nutrient digestibility and body weight change of Horro lambs fed a basal diet of native grass hay.

\section{MATERIALS AND METHODS}

\section{Description of the Study Area}

The study was conducted at Nekemte town of East Wollega Zone, Oromiya National Regional State. Nekemte is located at $9^{\circ} 6^{\prime} \mathrm{N}$ latitude and $37^{\circ} 9^{\prime}$ $\mathrm{E}$ longitude, $332 \mathrm{~km}$ west of Addis Ababa, at an average altitude of 1950 m.a.s.I (ADO, 2010). The area is characterized by a unimodal rainfall pattern and annual rainfall of $1244 \mathrm{~mm}$ and the minimum and maximum air temperature of $15^{\circ} \mathrm{C}$ and $28^{\circ} \mathrm{C}$, respectively. The rainy season occurs from April to September and maximum rain fall is received in the months of June, July and August. The Woreda has livestock population of 110,633 sheep and Goats, 51,274 cattle, 26,930 poultry and 5,028 equines and crops grown in the area are maize, sorghum, teff, noug, and beans.

\section{Experimental Animals and Their Management}

Twenty yearlings male Horro lambs with initial average live weight of $15.38 \pm 0.58$ (mean \pm SD), purchased from the local livestock market in Nekemte, were used in the experiment. The age of the animals was estimated to be around one year depending on the dentition and information from the owners. The animals were acclimatized to the environment and accustomed to the experimental feeds in small amounts for one month. During this period they were de-wormed, sprayed against
Sci. Technol. Arts Res. J., April-June 2013, 2(2): 30-37

external parasites and vaccinated against pasteurellosis, a disease commonly observed in the area. They were housed and fed in individual pens provided with feed troughs.

\section{Feeds Used in the Experiment}

Feeds used in the experiment were natural pasture hay, bought form Holeta town and nearby markets, used as a basal diet and graded levels (150, 300 and $450 \mathrm{~g} \mathrm{DM})$ of a mixture of dried green Vernonia amygdalina leaves (33\%) and ground sorghum grain (67\%) as supplement. The Vernonia leaves were air dried and crushed into small pieces using homemade wooden mortar and pestle, commonly used by the community in the area, to enable thorough mixing with the ground sorghum grain to minimize selection by the animals. The natural pasture hay was offered free choice for ad libtum consumption. The ground Vernonia leaves and sorghum grain mixture supplement was offered in two equal portions at $10 \mathrm{~h}$ in the morning and 14 $h$ in the afternoon local time. The experimental sheep had free access to drinking water.

\section{Experimental Design and Treatments}

A randomized complete block design was used for the experiment. At the end of the acclimatization period, the animals were grouped into four blocks of five animals each based on initial live-weight and animals from each block were randomly assigned to four treatment diets giving five lambs per treatment. The four treatment diets include:

Treatment 1 (T1; control, grass hay offered free choice but no supplement),

Treatment 2 (T2; free choice grass hay + 150g DM of $33 \%$ V. amygdalina leaves $+67 \%$ sorghum grain supplement),

Treatment 3 (T3; free choice grass hay $+300 \mathrm{~g} \mathrm{DM}$ $33 \%$ V. amygdalina leaves $+67 \%$ sorghum grain supplement), and

Treatment 4 (T4; hay ad lib $+450 \mathrm{~g}$ DM33\% $V$. amygdalina leaves $+67 \%$ sorghum grain supplement).

\section{Measurements and Observations \\ Feed Intake}

Feed offered to the lambs and corresponding refusals were recorded daily throughout the experimental period to determine daily feed intake. Intake was calculated as the difference between feed offered and refused on DM basis. Samples of feed offered were collected from each treatment while samples of refusal were taken from each sheep daily per treatment over the experimental period. This was pooled over the experimental period and sub-sampled for analysis. 
Firisa Woyessa et al.,

\section{Digestibility Trial}

The digestibility trial was conducted during the last phase of the experiment. The animals were adapted to the fecal bags for three days, which was followed by seven consecutive days of fecal collection. Feces voided were collected daily per animal and weighed every morning before feed offer. About $20 \%$ of sample was taken from the feces collected daily for each animal and composited in container (airtight plastics) and stored at $-20^{\circ} \mathrm{C}$ in a deep freezer till the end of the collection period. At the end of the collection period, the feces were taken to the laboratory, thoroughly mixed for each animal and sub-sample was taken to determine the chemical composition of the feces. Feed intake was recorded daily. The apparent digestibility of feed DM and nutrients were determined using the following equations:

\section{Apparent DM/nutrient digestibility= (DM/nutrient intake-DM/nutrient in feces)}

\section{DM/nutrient intake}

The metabolizable energy contents of the feeds were estimated from in vitro organic matter digestibility as described by (McDonald et al., 2002). $\operatorname{ME}(\mathrm{MJ} / \mathrm{kg})=0.016^{*} \mathrm{DOMD}$; Where $\mathrm{DOMD}=\mathrm{g}$ digestible organic matter per kg dry matter

\section{Body Weight Change}

The lambs were weighed at the beginning of the experiment and at 10 days interval thereafter until the end of the experiment after overnight fasting. The daily BW gain for each sheep was determined as a difference between the final and initial BW divided by the total number of actual feeding days. Feed conversion efficiency (FCE), which is the measure of efficiency of feed utilization, was calculated as unit of body weight gain per unit of feed consumed.

\section{Chemical Analysis}

Representative samples of daily feed offered and refused were collected, weighed and separately stored for each animal in bags and kept in a room with adequate natural ventilation until the end of the experimental period. Then the feed samples were thoroughly mixed, sub sampled and taken to the Holleta Agricultural Research Center Nutrition Laboratory for chemical analysis. The dry matter (DM), ash and nitrogen (N) content of sample of feed offered and refused and feces were analysed by the method of AOAC (1990) and, neutral detergent fiber (NDF), acid detergent fiber (ADF),
Sci. Technol. Arts Res. J., April-June 2013, 2(2): 30-37

and acid detergent lignin (ADL) in the samples of feeds that were offered, and from refusals and feaces were determined by the method of Van Soest and Robertson, (1985). The N content was determined by Kjeldahl technique and the crude protein (CP) content was calculated by multiplying $\mathrm{N}$ content with 6.25. In vitro organic matter digestibility was determined using procedures of Tilley and Terry (1963). Hemicelluloses content was calculated NDF-ADF whereas cellulose content was calculated as a differences between ADF and the sum of ADL and ADF ash.

\section{Statistical Analysis}

Analysis of variance was carried out using the General Linear Models procedure of the Statistical Analysis System (SAS, 2004) in a completely randomized block design to test the effects of graded levels of a mixture of dried Vernonia leaves and sorghum grain supplementation on feed intake, digestibility and body weight change of the sheep. Statistical significance of the difference between means were tested using the Least Significant Difference. The statistical model used for the experiment was as described below:

$$
\begin{aligned}
& \text { Yijk }=\mu+\alpha i+\beta j+\text { eijk } \\
& Y i j=\text { the observation in the ith treatment } \& \text { jth block } \\
& \mu=\text { the overall mean } \\
& \alpha i=\text { the ith treatment effect } \\
& \beta j=\text { the jth block effect } \\
& \text { eijk }=\text { the random error associated with Yijk }
\end{aligned}
$$

\section{RESULTS AND DISCUSSION}

\section{Chemical Composition of Treatment Diets}

The chemical composition of experimental feeds is shown in Table 1. The natural pasture hay had low CP $(5.5 \%)$ and high NDF $(76.3 \%)$, ADF (39.7\%) and ADL $(7.8 \%)$ contents. The high fiber content and low CP content of the natural pasture hay could be explained by different factors affecting the nutritive value of natural pasture hay such as varietal differences, location or climate, fertility of the land, stage of maturity at harvest, morphological fractions (e.g. leaf to steam ratio), harvesting and transporting practices, length and condition of storage time (Archimede et al., 2000; Ru and Fortune, 1999; Preston and Leng, 1984). The CP content falls below the minimum threshold level $(7 \%$ CP) for optimal rumen microbial activity, which necessitates supplementation with feeds having high protein content. 
Table 1: Chemical composition and in vitro OM digestibility of treatment feeds.

\begin{tabular}{llccc}
\hline \multirow{2}{*}{ Chemical Composition } & \multicolumn{4}{c}{ Treatment Feeds } \\
\cline { 2 - 5 } & Hay & Vernonia & Sorghum & VSM (33\%:67\%) \\
\hline DM (g/kg) & 928.9 & 917.4 & 884.5 & 895.4 \\
Ash (g/kg DM) & 25.9 & 47.9 & 4.6 & 18.9 \\
OM(g/kg DM) & 903.0 & 869.5 & 879.9 & 876.5 \\
CP(g/kg DM) & 54.8 & 226.4 & 102.6 & 142.0 \\
NDF(g/kg DM) & 762.6 & 386.8 & 136.3 & 218.9 \\
ADF(g/kg DM) & 396.7 & 220.2 & 77.0 & 134.3 \\
ADL(g/kg DM) & 77.8 & 50.6 & 20.1 & 39.2 \\
Hemicelluloses(g/kg DM) & 365.9 & 166.6 & 59.3 & 84.6 \\
Cellulose(g/kg DM) & 346.1 & 142.4 & 56.9 & 95.1 \\
EME (MJ/kg DM) & 8.47 & 11.99 & 14.8 & 13.87 \\
IVOMD (g/kg DM) & 529.6 & 749.9 & 925.0 & 867.22 \\
\hline EME =Estimated Metabolizable Energy, IVOMD=In Vitro Organic Matter Digestibility,
\end{tabular}

The CP contents of the supplementary diets, namely, Vernonia leaves and ground sorghum grain were $22.6 \%$ and $10.3 \%$, respectively. The OM content of Vernonia and sorghum grain mixtures in this experiment $(87.6 \%)$ was higher than the result of Vernonia foliage-maize grain mixtures $(81.8 \%)$ reported by Amensisa, (2010). The NDF and ADF contents of Vernonia leaves $(38.7 \%$ and $22 \%$, respetively) in the current study were lower than the values of NDF and ADF values $(44.8 \%$ and $36.7 \%$, respectively) reported by Amensissa, (2010). In general, the natural pasture hay had low CP and high fiber content whereas the Vernonia-sorghum grain mixture (VSM) had lower fiber content. The high CP content of the feed supplements (Vernonia leaves $=22.6 \%$ ), suggests that there is a potential for supplementing the low quality feeds by locally available protein rich tree leaves to improve animal performance.

According to Lonsdale, (1989), feeds that have $<120,120-200$ and $>200 \mathrm{~g} \mathrm{CP} / \mathrm{kg}$ DM and $<9,9-$ 12 and $>12 \mathrm{MJ}$ ME/kg DM are classified as low, medium and high protein and energy sources, respectively. The basal diet, natural pasture hay, used in this experiment with CP content of $54.8 \mathrm{~g} / \mathrm{kg}$
DM and 8.47 MJ EME/kg DM could be considered as low protein and energy feed source.

\section{Dry Matter and Nutrient Intake}

The mean daily DM and nutrient intake of lambs fed natural pasture hay alone or supplemented with mixtures of Vernonia leaves and ground sorghum grain is presented in Table 2. The total daily DM intake was highest $(P<0.001)$ for T3 followed by T4 and T2. The least DM intake was recorded for the lambs kept on natural pasture hay (T1). This was probably due to the low $\mathrm{CP}$ and high fiber contents of the natural pasture hay, which is likely to depress both feed intake and digestibility. High NDF content above $55 \%$ can limit DM intake (Van Soest, 1967), which is the case in the unsupplemented groups of animals. Generally, the results indicated that supplementation of natural pasture hay with VSM significantly improved $(P<0.001)$ total DMI. This could be attributed to high rumen degradable protein content of the supplements which might have enhanced the efficiency of rumen microorganisms that increase fiber degradability and digestibility thereby improved feed intake (McDonald et al., 2002). 
Table 2: Daily dry matter and nutrient intakes of Horro lambs fed natural pasture hay alone or supplemented with graded levels of mixture of ground Vernonnia leaves and ground sorghum grain.

\begin{tabular}{|c|c|c|c|c|c|c|}
\hline \multirow{2}{*}{ Parameters } & \multicolumn{6}{|c|}{ Treatments } \\
\hline & T1 & T2 & T3 & T4 & SEM & SL \\
\hline \multicolumn{7}{|l|}{ Dry Matter Intake } \\
\hline Natural Pasture Hay (g/d) & $190.1^{\mathrm{d}}$ & $334.4^{c}$ & $606.8^{a}$ & $519.1^{b}$ & 26.8 & *** \\
\hline Supplemented (g/d) & $0^{d}$ & $130.9^{c}$ & $236.6^{\mathrm{b}}$ & $351.8^{\mathrm{a}}$ & 7.7 & $* * *$ \\
\hline Total DM (g/d) & $190.1^{c}$ & $465.3^{b}$ & $883.3^{\mathrm{a}}$ & $870.9^{a}$ & 37.6 & $* * *$ \\
\hline Total DM (\%BW) & $3.3^{b}$ & $4.1^{\mathrm{a}}$ & $2.8^{\mathrm{c}}$ & $2.4^{\mathrm{c}}$ & 0.15 & $* * *$ \\
\hline \multicolumn{7}{|l|}{ Nutrient Intake (g/d) } \\
\hline Total OM & $184.8^{\mathrm{C}}$ & $453.2^{b}$ & $825.5^{\mathrm{a}}$ & $849.0^{\mathrm{a}}$ & 35.6 & $* * *$ \\
\hline Total CP & $11.2^{d}$ & $40.5^{\mathrm{c}}$ & $74.0^{\mathrm{b}}$ & $86.4^{\mathrm{a}}$ & 2.5 & $* * *$ \\
\hline Total NDF & $156.0^{c}$ & $306.6^{b}$ & $512.1^{\mathrm{a}}$ & $557.0^{\mathrm{a}}$ & 29 & $* * *$ \\
\hline Total ADF & $81.2^{\mathrm{c}}$ & $162.5^{\mathrm{b}}$ & $295.2^{\mathrm{a}}$ & $274.4^{\mathrm{a}}$ & 15.14 & $* * *$ \\
\hline Total ADL & $10.4^{\mathrm{c}}$ & $24.0^{\mathrm{b}}$ & $45.2^{\mathrm{a}}$ & $43.7^{\mathrm{a}}$ & 2.3 & $* * *$ \\
\hline \multicolumn{7}{|c|}{ 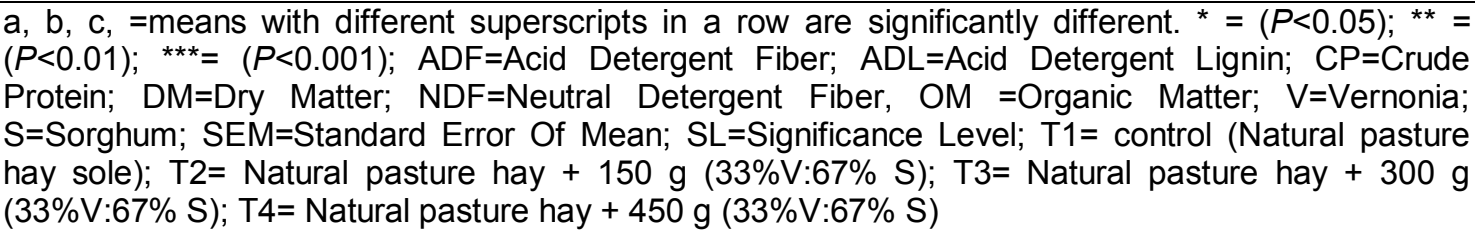 } \\
\hline
\end{tabular}

The results agreed with the findings of (Yoseph, 1999) that showed supplementation of concentrate diets (atella) to sheep maintained on hay basal diet, increased the total and basal DM intake as compared to pulse hull supplemented ones. In the current study, the lower NDF and ADF contents of VSM might be the major factors contributing to increase intakes of the supplement diets by reducing gut fill and optimizing rate of passage (Amensisa, 2010). Dietary protein supplementation is known to improve intake by increasing the supply of nitrogen to the rumen microbes. This has positive effect on increasing rumen microbial population and efficiency, thus enabling them to increase the rate of breakdown of the digesta. When the rate of breakdown of digesta increases, feed intake is accordingly increased (Van Soest, 1982). On the other hand, Grovum and Williams, (1977) reported that if the ingested feed is retained longer in the rumen, it is expected that the animal would consume less feed, because of the occupied space or 'gut fill'. On the other hand, rate of passage would be quicker as intake increases leaving less time for feed to be digested in the rumen. Supplementary diets in this study improved the total DMI by 81.2 , 62.8 and 60.9 percent over non-supplemented natural pasture hay for T4, T3 and T2 respectively.

\section{Dry Matter and Nutrient Digestibility}

The digestibility of DM and nutrients by sheep fed natural pasture hay basal diet and supplemented with VSM is presented in Table 3.
Supplementation significantly improved $(P<0.001)$ the $\mathrm{DM}, \mathrm{OM}, \mathrm{CP}$ and fiber components digestibility of the diet. Mulat (2006) reported that digestibilities of DM, OM, CP, NDF and ADF for sheep fed a basal diet of finger millet straw were improved when supplemented with different protein sources. Digestibility also decreases with increased ADF content and increased lignifications of the fiber (McDonald et al., 2002). As the amount of nitrogen required by the rumen micro flora is related to the amount of fermentable energy potentially available, Vernonia could also serve as a complementary diet for feeds which are high in readily fermentable energy sources for their efficient utilization of nitrogen by rumen microbes to serve microbial protein synthesis.

The digestibility of DM increased by $59.8,50.2$ and $44.4 \%$ in response to supplementation for T2, T3 and T4, respectively, over non-supplemented diets. The lower apparent digestibility of nutrients in non-supplemented groups compared with the supplemented ones could be associated with the lower CP in the feeds offered for control group (Table 3). Fecal CP losses as a percentage of CP intakes for supplemented treatments were 34.5, 35.7 and $34.7 \%$ for T2, T3, and T4 respectively. In this study, the digestible DM, OM, CP, NDF and ADF intakes were higher $(P<0.001)$ for supplemented than non-supplemented lambs (Table $3)$. 
Table 3: Daily dry matter and nutrient digestibility of Horro lambs fed natural pasture hay alone or supplemented with mixtures of ground Vernonia leaves and ground sorghum grain at different proportions.

\begin{tabular}{lllllll}
\hline \multirow{2}{*}{ Parameters } & \multicolumn{7}{c}{ Treatments } \\
\cline { 2 - 7 } Digestibility \% & T1 & T2 & T3 & T4 & SEM & SL \\
DM & $69^{\mathrm{b}}$ & $81^{\mathrm{a}}$ & $71^{\mathrm{b}}$ & $89^{\mathrm{a}}$ & 0.03 & $*$ \\
OM & $72.6^{\mathrm{b}}$ & $83.8^{\mathrm{a}}$ & $73.4^{\mathrm{b}}$ & $90.2^{\mathrm{a}}$ & 0.03 & $*$ \\
CP & $35.6^{\mathrm{c}}$ & $39.6^{\mathrm{b}}$ & $59.4^{\mathrm{b}}$ & $86.8^{\mathrm{a}}$ & 0.15 & $* * *$ \\
NDF & $73.4^{\mathrm{bc}}$ & $80.8^{\mathrm{ab}}$ & $67.4^{\mathrm{c}}$ & $87^{\mathrm{a}}$ & 0.03 & $*$ \\
ADF & 60.8 & 64.4 & 55.4 & $58.4^{*}$ & 0.15 & $\mathrm{Ns}$ \\
Digestible Nutrient Intake (g/d) & & & & & & \\
DM & $132.3^{\mathrm{c}}$ & $386.4^{\mathrm{b}}$ & $637.2^{\mathrm{a}}$ & $773.4^{\mathrm{a}}$ & 45.4 & $* * *$ \\
OM & $135.7^{\mathrm{c}}$ & $384.5^{\mathrm{b}}$ & $662^{\mathrm{a}}$ & $765.6^{\mathrm{a}}$ & 39.8 & $* * *$ \\
CP & $4.2^{\mathrm{d}}$ & $28.5^{\mathrm{c}}$ & $44.5^{\mathrm{b}}$ & $75.01^{\mathrm{a}}$ & 4 & $* * *$ \\
NDF & $115.5^{\mathrm{b}}$ & $351.4^{\mathrm{a}}$ & $383.9^{\mathrm{a}}$ & $445^{\mathrm{a}}$ & 62 & $\mathrm{Ns}$ \\
ADF & $50.1^{\mathrm{b}}$ & $109.5^{\mathrm{b}}$ & $208.3^{\mathrm{a}}$ & $220.2^{\mathrm{a}}$ & 22.3 & $*$ \\
\hline
\end{tabular}

a, b, c, =means with different superscripts in a row are significantly different. ${ }^{* \star *}=(P<0.001)$; ${ }^{* *}=(P<0.01) ;{ }^{*}(P<0.05)$.

\section{Body Weight Gain of Horro Lambs}

The body weight (BW) change of experimental sheep on the different treatment feeds is given in Table 4. The average daily BW gain of sheep supplemented with ground Vernonia leaves and ground Sorghum grain mixture at $450 \mathrm{~g} / \mathrm{d}$ (T4) and $300 \mathrm{~g} / \mathrm{d}(\mathrm{T} 3)$ was significantly different $(P<0.001)$ from T2, which in turn higher than T1. The nonsupplemented sheep had got significantly lower $(P<0.001)$ daily BW gain than those supplemented with 450,300 and $150 \mathrm{~g} / \mathrm{d}$. Based on the lower nutrient intake and digestibility for lambs that were not supplemented, such differences are expected. The higher $(P<0.001)$ average daily BW gain of $40.0,81.3$ and $93.8 \mathrm{~g} / \mathrm{lamb} / \mathrm{d}$ was recorded for lambs in T2, T3, and T4 as compared to nonsupplemented groups $(7.6 \mathrm{~g} / \mathrm{d})$, respectively, and the BW gain tended to increase for the higher $\mathrm{CP}$ intakes.

Table 4: Body weight change of Horro lambs fed natural pasture hay supplemented with different levels of ground Vernonia leaves and ground sorghum grain mixtures.

\begin{tabular}{lcccccc}
\hline \multirow{2}{*}{ Parameters \% } & \multicolumn{7}{c}{ Treatments } \\
\cline { 2 - 7 } & T1 & T2 & T3 & T4 & SEM & SL \\
\hline Initial weight (kg) & 15.0 & 15.1 & 15.6 & 15.8 & 0.26 & Ns \\
Final weight (kg) & $15.6^{\mathrm{c}}$ & $18.3^{\mathrm{b}}$ & $22.1^{\mathrm{a}}$ & $23.3^{\mathrm{a}}$ & 0.81 & $* * *$ \\
ADG (g) & $7.6^{\mathrm{c}}$ & $40.0^{\mathrm{b}}$ & $81.3^{\mathrm{a}}$ & $93.8^{\mathrm{a}}$ & 8.9 & $* * *$ \\
Weight change (kg) & $0.6^{\mathrm{c}}$ & $3^{\mathrm{b}}$ & $7^{\mathrm{a}}$ & $8^{\mathrm{a}}$ & 0.71 & $* * *$ \\
FCR (g DMl/g BWG) & 25.6 & 11.6 & 10.9 & 9.3 & 6.18 & $\mathrm{Ns}$ \\
FCE (g BWG/ g DMI) & 0.4 & 0.09 & 0.09 & 0.11 & 0.02 & $\mathrm{Ns}$ \\
\hline
\end{tabular}

abc Means with different superscripts in the same row are significantly different $(P<0.05) ;{ }^{* *}(P<0.001) ;{ }^{* *}(P<0.01) ;{ }^{*}(P<0.05)$; ns: not significant; SEM: Standard Error of Mean; DMI: Dry Matter Intake; FCR: Feed Conversion Ratio; ADG: Average Daily Body Weight Gain. 


\section{Firisa Woyessa et al.,}

The daily BW gain among supplemented sheep in T3, and T4 was similar. This result reflected that the supplements were comparable in their potential to supply nutrients for improving the weight gains of lambs, which indicates that it may not be economically beneficial to give more than 300 $\mathrm{g} / \mathrm{head} /$ day of the supplement.

\section{Feed Conversion Efficiency}

The Feed conversion efficiency (FCE) of lambs supplemented with mixtures Vernonia leaves and ground sorghum grain is presented in Table 4. The FCE was significantly improved $(P<0.001)$ for supplemented groups relative to the nonsupplemented ones. It was highest $(P<0.001)$ for the lambs fed on T4 followed by T3 and T2 as compared to T1. The improved FCE seemed to be related to higher nutrient concentration of the supplements and the consequent increase in BW gain (Table 4). In general, supplementation improved both feed conversion efficiency and daily body weight gain of the experimental animals in the present study.

\section{CONCLUSION}

The Supplementation of Horro lambs with Vernonia leaves and ground sorghum grain mixture improved feed intake, nutrient digestibility, daily body weight gain and feed conversion efficiency. The performance at highest level of supplementation $(450 \mathrm{~g} / \mathrm{head} /$ day $)$ was not significantly different from the $300 \mathrm{~g} / \mathrm{head} /$ day level of supplementation for most variables measured and there may not economic advantage for supplementing beyond $300 \mathrm{~g}$ in this case.

\section{ACKNOWLEDGEMENT}

The authors appreciate the cooperation of the staff of Animal Nutrition Laboratory at Holetta Agricultural Research Center for their help in chemical analysis of the samples.

\section{REFERENCE}

Agricultural Development Office (ADO) Report of Guto Gida Woreda (2010). Annual reports of agricultural operation.

Amensisa Eresso, (2010). Effect of supplementation of dried "Grawa" (vernonia amygdalina) foliage and crushed maize grain mixtures on feed intake, digestibility and body weight change of Horro sheep fed natural pasture hay. MSc. Thesis. Haramaya University Ethiopia. Pp. 35-47.

AOAC, (1990). Official methods of analysis, $15^{\text {th }}$ edition association of Analytical chemists (AOAC). In C,Artington, Verginia, USA.
Sci. Technol. Arts Res. J., April-June 2013, 2(2): 30-37

Archimede H., Boval, M. and Alexandre, G. (2000). Effect of regrowth age on intake and digestion of Digitaria decumbens consumed by Black-Belly sheep. Animal Feeds Science and Technology_87(3-4): 153-162.

Aynalem Haile and Taye Tolemariam, (2008). The feed values of indigenous multipurpose trees for sheep in Ethiopia: the case of vernonia amygdalina, buddleja polystachya and maesa lanceolata. Livestock Research for Rural Development 20(3): 1-7.

Berhanu Belay and Aynalem Haile, (2009). Factors affecting growth performance of sheep under village management conditions in the south western part of Ethiopia. Livestock Research for Rural Development 21(11): 1-8.

CSA (Central Statistical Authority), (2008). Summary and Statistical Report of the 2007 Population and Housing Census, Addis Ababa, Ethiopia. Pp114.

Grovum, W.L. and William, J.V. (1977). Rate of passage of digesta in sheep. The effect of food intake on mathematical prediction of the kinetics of digesta in the reticulo-rumen and intestines. British Journal of Nutrition 38: 425-436.

Kassahun Awgichew, (2000). Comparative performance evaluation of Horro and Menz sheep of Ethiopia under grazing and intensive feeding conditions. PhD dissertation. Animal Science. Unverisity of Wales, Uk. Pp 173.

Lonsdale, C. (1989). Raw Materials for Animal Feed Compounders and Farmers. Chalcombe Publications. Pp 88.

McDonald, P., Edwards, R.D Greenhangh, J.F.D and Morgan, C.A. (2002). Animal Nutrition. $6^{\text {th }}$ ed. Prentice Hall, London. pp 583-59.

MoA (Ministry of Agriculture), (1999). Live Stock Development Technical Report. A National Workshop on Live Stock Development. Animal and Fisheries Resources and Health Technology Development and Regulatory Main Department, MoA (Ministry of Agriculture), Addis Ababa, Ethiopia. 11-14 March 1999.

Mulat Alem, (2006). Effects of Supplementing Different Protein Sources on Feed intake and Live Weight Gain of Local Sheep Fed on Finger Millet (Eleucine coracana) Straw Basal Diet. MSc. Thesis. Alemaya University Ethiopia.

NRC, (1996). Nutrient requirement of sheep. Sixth revised ed. National Academy press, Washington, DC (USA).

Preston, T.R. and Leng, R.A. (1984). Supplementation of diets based on fibrous residues and by-products. pp. 373-409. In: F. Sundstol and E. owen (eds.). Straw and other fibrous byproducts feed. Elsevier Publishing Company. Amsterdam.

Ru, Y.J. and Fortue, J.A. (1999). Sward characteristics and nutritive value of two cultivars of subterranean clover. Asian-Australian Journal of Animal Science 12(8): 1192-1199.

SAS (Statistical Analysis System) (2004). SAS/STAT 9.1 User's Guide, SAS Institute, Cary, N.C., USA. 
Firisa Woyessa et al.,

Tilley, J.M.A. and Terry, R.A, (1963). A two stage technique for in vitro digestion of forage crops. Journal of the British Grassland Society 18:104.

Van Soest, P.J., (1982). Nutritional Ecology of the Ruminant, $\mathrm{O}$ and $\mathrm{B}$ books Corvallis, Oregon, USA.

Van Soest, P.J. (1967). Development of Comparative system of feed analysis and its application to forages. Journal of Animal Science 26:119-128.

Van Soest, P.J. and Robertson, J.B, (1985). Analysis of forage and fibrous foods. A laboratory manual for
Sci. Technol. Arts Res. J., April-June 2013, 2(2): 30-37

Animal Science 613 Cornell University, Ithaca, New York, USA.

Yoseph Mekasha, (1999). Impact of Feed Resource on Productive and Reproductive Performance of Dairy Cows in the Urban and Peri urban Dairy Production System in the Addis Ababa Milk Shed Area and Evaluation of Non-conventional Feed Resources Using Sheep. MSc. Thesis. Haramaya University Ethiopia. Pp.118. 